\title{
HAEMIN AND NICOTINAMIDE ADENINE DINUCLEOTIDE REQUIREMENTS OF HAEMOPHILUS INFLUENZAE AND HAEMOPHILUS PARAINFLUENZAE
}

\author{
Nora M. Evans,* D. D. Smith* and A. J. Wicken $\dagger$ \\ *The Prince of Wales Hospital, Randwick, NSW, and \\ $\dagger$ School of Microbiology, University of New South Wales, Kensington, NSW, Australia
}

\section{Plate XIV}

HaEMOPHILUS INFLUeNZAe requires haemin and nicotinamide adenine dinucleotide (NAD) for growth but $H$. parainfluenzae requires NAD only, and it is essentially on these nutritional characters that the two species are distinguished (Pittman, 1957). In practice, however, the determination of these requirements may be unreliable because basal media may contain traces of haemin (Zinnemann, 1960). H. influenzae grown on such media might appear to have no haemin requirement and be erroneously identified as $H$. parainfluenzae; also, the haemin present in heavy inocula could lead to the same conclusion (Biberstein and Gills, 1961; Parker and Hoeprich, 1962; Koser, 1968; Klein and Blazevic, 1969; Evans and Smith, 1972; Michaels and Phillips, 1972).

It has been suggested (Smith, Hale and O'Callaghan, 1953; Biberstein and Gills, 1961) that a sharp division into two distinct species may be an oversimplification and that $H$. parainfluenzae may merely represent one end of a wide series of $H$. influenzae strains ranging from those without the ability to synthesise haemin to those capable of growth in haemin-free media. Turk and May (1967) also consider that there is no point in distinguishing between the non-encapsulated strains of the two species and regard as rare strains that do not require some haemin for growth.

Hitherto, different media and techniques have been employed to measure haemin and NAD requirements for growth. One apparently significant variation was the size of the inoculum, which ranged from single cells on agar media to as high as $10^{7}$ cells for cultures in fluid media (Gilder and Granick, 1948; Brumfitt, 1959; Butler, 1962; Parker and Hoeprich, 1962).

In this study an attempt has been made to clarify the position by measuring the haemin and NAD requirements of strains of $H$. influenzae and $H$. parainfluenzae on a medium considered to be free of haemin and employing very small inocula.

\section{MATERIALS AND METHODS}

Media. The basal medium used throughout contained (w/v) Proteose Peptone Broth (Difco) $2 \%, \mathrm{NaCl} 0.6 \%$, sodium dithionite $\left(\mathrm{Na}_{2} \mathrm{~S}_{2} \mathrm{O}_{4}+\mathrm{H}_{2} \mathrm{O}\right) 0.01 \%$ (Gilder and Granick, 1948), and glucose $0.2 \%$, supplemented with thiamin hydrochloride $1 \mu \mathrm{g}$ per ml and sodium

Received 17 Dec. 1973; accepted 31 Dec. 1973.

J. MED. MICROBIOL.-VOL. 7 (1974) 
oleate $4.8 \mu \mathrm{g}$ per ml (Evans and Smith, 1972), and solidified with Oxoid Ionagar no. $21.2 \%$ $(w / v)$. A clear agar similar to Levinthal's agar, referred to as $X-V$ agar, contained in addition to the above ingredients, fresh yeast extract $1 \%(\mathrm{v} / \mathrm{v})$ and lysed horse-blood $0 \cdot 25 \%(\mathrm{v} / \mathrm{v})$. For fluid cultures, the preparation of proteose peptone differed from the basal medium in containing yeast extract $1 \%(\mathrm{v} / \mathrm{v})$ and haemin $20 \mu \mathrm{g}$ per ml but no dithionite or thiamin. Proteose peptone broth used for washing and suspending the cells contained $(\mathrm{w} / \mathrm{v})$ only Proteose Peptone $2 \%$ and $\mathrm{NaCl} 0.6 \%$. Chocolate agar (Cruickshank, 1965) was prepared from the basal medium with the addition of $7.5 \%$ of difibrinated horse-blood. Sterilisation of the basal medium was at $10 \mathrm{lbs}$ per in. ${ }^{2}\left(0.7 \mathrm{~kg}\right.$ per $\left.\mathrm{cm}^{2}\right)$ steam pressure for $20 \mathrm{~min}$., before glucose or supplements were added.

Organisms. All strains were Gram-negative rods, non-haemolytic on horse-blood agar, and were from type-culture collections or freshly isolated from cerebrospinal fluid, sputum, throat, and ear swabs cultured on X-V agar which usually contained 2.5 units of bacitracin per $\mathrm{ml}$ as a selective agent (Crawford, Barden and Kirkman, 1969; Hovig and Aandahl, 1969). Haemin and NAD requirements were determined by a satellitism test on the basal agar medium with and without haemin and with an inoculum standardised to give discrete colonies; a paper disk containing $15 \mu \mathrm{g}$ of NAD was placed on the surface of each seeded plate (Smith and Evans, 1972). Encapsulated strains of $H$. influenzae were also typed by capsular swelling with $H$. influenzae antisera a-f (Burroughs Wellcome). Of 50 strains of $H$. influenzae, 43 were freshly isolated including 14 encapsulated of type $b$, and seven were reference strains, no. NCTC4560 (unencapsulated), no. NCTC8465 (type a), no. NCTC7279 (type b), no. NCTC8469 (type c), no. NCTC8470 (type d), no. NCTC10479 (type e), and no. NCTC8473 (type f). Thirty strains of $H$. parainfluenzae included 29 freshly isolated strains of which three required oleate and three thiamin, and a reference strain no. NCTC10665.

Chemicals and growth factors. Aqueous stock solutions of NAD ( $\beta$ NAD, Sigma Chemical Co. Ltd) and haemin (Koch-Light), as recommended by Turk and May, 1967), each contained $2000 \mu \mathrm{g}$ per ml; thiamin hydrochloride (E. Merck) $10,000 \mu \mathrm{g}$ per ml, sodium oleate (Sigma Chemical Co. Ltd) $12,000 \mu \mathrm{g}$ per $\mathrm{ml}$ and glucose (Univar, Ajax Chemicals Ltd) $20 \%(\mathrm{w} / \mathrm{v})$ were prepared in glass-distilled water; solutions were sterilised by filtration through a $0.45 \mu$ Swinnex Millipore filter unit, and were added to the medium at $53^{\circ} \mathrm{C}$. Potassium nitrate $\left(\mathrm{KNO}_{3}\right.$, Univar, Ajax Chemicals Ltd) was included at a final concentration of $0.1 \%$ (Gilder and Granick, 1948). Yeast extract was prepared from fresh baker's yeats (Lwoff and Lwoff, 1937), and stored deep frozen.

Inocula for determination of quantitative haemin and NAD requirements. Overnight chocolate-agar cultures were used to seed 10-ml amounts of broth in $30 \mathrm{ml}$ screw-capped containers which were shaken in a water bath for 6 hours at $37^{\circ} \mathrm{C}$. Organisms were recovered by centrifugation and washed four times in proteose peptone broth before being resuspended in the same medium. Ten-fold dilutions of these washed cell suspensions were seeded on duplicate plates by a multiple inoculating device (Steers, Foltz and Graves, 1959); the volume of inocula was $4 \mu 1$ and the smallest inoculum contained 1-20 cells. In later experiments, it was found that the washing process was unnecessary and that inocula could be prepared by suspending one colony from a chocolate-agar culture in $2.5 \mathrm{ml}$ of proteose peptone broth; the suspension thus obtained was diluted 1 in 10,000 and contained 1-20 viable units in $4 \mu \mathrm{l}$.

Culture conditions. All aerobic cultures were incubated for 24 hours in an atmosphere of $5 \% \mathrm{CO}_{2}$ in air $(\mathrm{v} / \mathrm{v})$ at $37^{\circ} \mathrm{C}$. Anaerobic cultures were incubated for 48 hours in an atmosphere of hydrogen with $5 \% \mathrm{CO}_{2}(\mathrm{v} / \mathrm{v}$, ) in a McIntosh and Fildes jar with a palladium chloride cold-catalyst (Baird and Tatlock); a Lucas, semi-solid, anaerobic indicator (Willis, 1964) was used routinely and the efficiency of the anaerobic system was checked regularly with a bloodagar culture of Clostridium tetani.

Estimation of growth on solid media. The main criterion of growth was that the colonies developing were uniform in number and size, and were comparable in number with those on control plates of chocolate agar. Colony sizes were measured with a microscope with a $\times 3.5$ lens and a micrometer eyepiece, or a measuring magnifier. 


\section{RESULTS}

The NAD requirement of $H$. influenzae and $H$. parainfluenzae in air with $5 \% \mathrm{CO}_{2}$

The amount of NAD required for the growth of 50 strains of $H$. influenzae and 30 strains of $H$. parainfluenzae was determined on the complete basal medium containing $20 \mu \mathrm{g}$ haemin per $\mathrm{ml}$ and with an inoculum of 1-20 cells. For the growth of all 80 strains of both species the least amount of NAD required was $5 \mu \mathrm{g}$ per $\mathrm{ml}$; colony counts were comparable with those on chocolate agar as were the colony sizes, which averaged $1.5 \mathrm{~mm}$ diameter for

TABLE

The effect of NAD concentration on the colony size of representative strains of Haemophilus influenzae and $H$. parainfluenzae from an inoculum of $1-20$ cells

\begin{tabular}{|c|c|c|}
\hline \multirow{2}{*}{ Medium } & \multicolumn{2}{|c|}{ Colony diameter $(\mathrm{mm})$ of } \\
\hline & H. influenzae & H. parainfluenzae \\
\hline $\begin{array}{c}\text { Basal agar + haemin } 20.0 \mu \mathrm{g} \mathrm{per} \mathrm{ml} \\
\text { + NAD } 0.008 \mu \mathrm{g} \mathrm{per} \mathrm{ml} \\
0.04 \mu \mathrm{g} \text { per ml } \\
0.2 \mu \mathrm{g} \text { per ml } \\
1.0 \mu \mathrm{g} \text { per ml } \\
5.0 \mu \mathrm{g} \text { per ml } \\
25.0 \mu \mathrm{g} \text { per ml }\end{array}$ & $\begin{array}{l}0 \\
0 \\
0.1-0.5 \\
1.0 \\
1.5 \\
1.5 \\
1.5 \\
1.5\end{array}$ & $\begin{array}{l}0 \\
0 \\
0 \\
0 \\
0 \cdot 5 \\
1 \cdot 0 \\
1 \cdot 0 \\
1 \cdot 0\end{array}$ \\
\hline
\end{tabular}

unencapsulated strains and $2.0 \mathrm{~mm}$ for encapsulated strains of $H$. influenzae and $1.0 \mathrm{~mm}$ for $H$. parainfluenzae. Three unencapsulated strains of $H$. influenzae had colonies of small size, ranging from 0.2 to $0.7 \mathrm{~mm}$; of these one was $\mathrm{CO}_{2}$-dependent and the other two also grew poorly on chocolate agar.

With the exception of three oleate-requiring strains of $H$. parainfluenzae, which required NAD $25 \mu \mathrm{g}$ per $\mathrm{ml}$ for maximal growth, appreciable difference in colonial size or number was not observed with concentrations of NAD over $5 \mu \mathrm{g}$ per $\mathrm{ml}$. The most common effect of the concentration of NAD on the colony size of a typical strain of each of the two species is recorded in the table.

With a decrease in NAD concentration to $1.0 \mu \mathrm{g}$ per $\mathrm{ml}$, the size and numbers of colonies of $H$. influenzae strains remained unchanged. Of the 30 strains of $H$. parainfluenzae however, 14 either failed to grow at all, or grew with small and variable-sized colonies averaging $0.5 \mathrm{~mm}$ diameter. Further reductions of the NAD concentration to $0.2 \mu \mathrm{g}$ per ml resulted in the growth of only two strains of $H$. parainfluenzae, one appearing as tiny colonies of $0.2 \mathrm{~mm}$ the other as colonies of $0.8 \mathrm{~mm}$ diameter. All 50 strains of $H$. influenzae continued to grow from small inocula with NAD $0.2 \mu \mathrm{g}$ per ml, but colony diameters were slightly reduced $(0 \cdot 8-1 \cdot 2 \mathrm{~mm})$.

Even at a lower concentration of NAD $(0.04 \mu \mathrm{g}$ per ml) at least half of the $H$. influenzae strains continued to grow from inocula of 1-20 cells although 
colony sizes were further reduced and variable $(0.2-0.5 \mathrm{~mm})$; no strains of $H$. parainfluenzae gave visible growth at this concentration. With an NAD concentration of $0.008 \mu \mathrm{g}$ per ml there was no growth of any of the strains of either species, even with a ten-fold increase in inoculum size.

Of the 30 strains of $H$. parainfluenzae, three did not grow in the absence of oleate, but when this substance was present, or on chocolate agar, these strains produced colonies of a larger diameter, approximately $2.0 \mathrm{~mm}$, compared with the $1.0 \mathrm{~mm}$ of the other strains. Three thiamin-requiring strains produced colonies of the smaller size on the complete basal medium.

\section{Haemin requirement of $\mathrm{H}$. influenzae in air with $5 \% \mathrm{CO}_{2}$}

The $50 \mathrm{H}$. influenzae strains grew on the basal medium containing haemin $20 \mu \mathrm{g}$ and NAD $1 \mu \mathrm{g}$ per $\mathrm{ml}$ from inocula of 1-20 cells. The size and number of the colonies were similar to those of colonies on chocolate agar; no strain grew in the absence of haemin. Further examination of the haemin requirements of 10 strains showed that the minimum requirement for optimum growth ranged between 2 and $10 \mu \mathrm{g}$ per ml; at concentrations of less than $2 \mu \mathrm{g}$ per ml the colony size of all strains was progressively diminished until at a concentration of $0.05 \mu \mathrm{g}$ per ml there was no growth; with larger inocula of $100-1000$ cells, some strains showed visible but slight growth at this concentration of haemin.

\section{Growth of $\mathrm{H}$. influenzae in hydrogen with $5 \% \mathrm{CO}_{2}$}

Four strains of $H$. influenzae, including two encapsulated type-b strains, were grown anaerobically on the basal medium containing NAD but no haemin. After 10 serial subcultures, with inocula of 1-20 cells on each occasion, the numbers of colonies of each strain were similar to those on chocolate agar incubated in air with $5 \% \mathrm{CO}_{2}$ but the colony size was smaller and was $0.7-$ $1.0 \mathrm{~mm}$ after 48 hours' incubation. Glucose was essential for full growth of the inoculum and in its absence the number and size of colonies developing was diminished. Six other strains grew anaerobically on three separate occasions, also from the same small inocula.

The separate addition of either haemin or potassium nitrate to the basal medium containing NAD had no effect but the addition of both haemin and nitrate resulted in increased colony sizes, which averaged $1.2 \mathrm{~mm}$ at 48 hours.

$$
\text { Growth of } \mathrm{H} \text {. parainfluenzae in hydrogen with } 5 \% \mathrm{CO}_{2}
$$

Thirty strains of $H$. parainfluenzae were also cultured anaerobically with NAD $5 \mu \mathrm{g}$ per $\mathrm{ml}$ on the basal medium. Potassium nitrate was essential for some strains and enhanced the growth of the remainder which, in the absence of nitrate, produced colonies small and variable in size.

\section{Discussion}

$H$. influenzae is characterised by its morphology and requirement for $\mathrm{X}$ and $\mathrm{V}$ factors when grown on nutrient media. The identity of $\mathrm{X}$ factor as haemin 

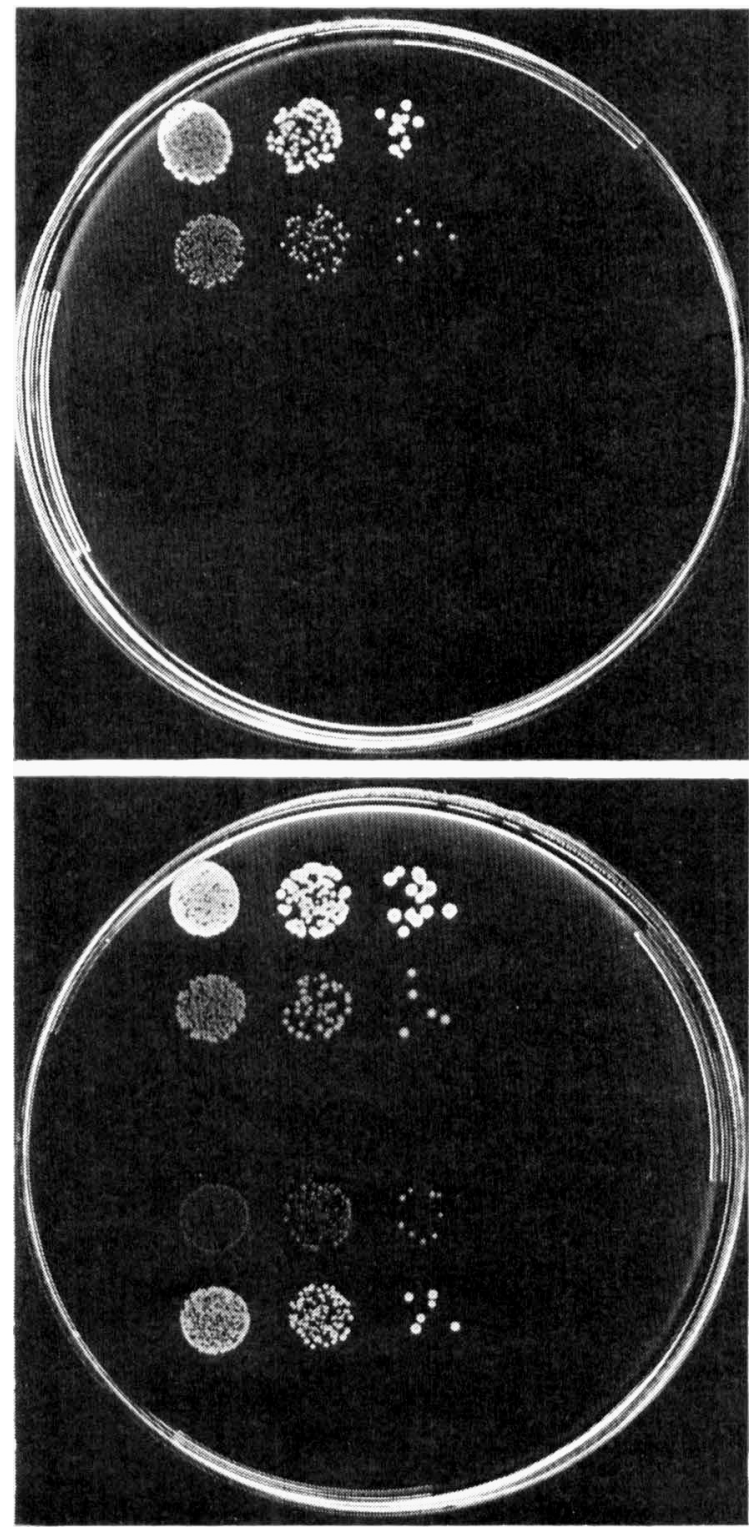

FIGURE.-Growth after 24 hours on plates containing basal medium +haemin $20 \mu \mathrm{g}$ per ml, with the addition of NAD (above) $0.2 \mu \mathrm{g}$ per ml and (below) $5.0 \mu \mathrm{g} \mathrm{per} \mathrm{ml;} \mathrm{upper} \mathrm{halves} \mathrm{of} \mathrm{plates,} \mathrm{two}$ strains of Haemophilus influenzae; lower halves, two strains of $H$. parainfluenzae. Three 10-fold dilutions of each culture were used as inocula. 
was established by Fildes (1921). H. parainfluenzae was subsequently recognised as a distinct species by its requirement of V factor only (Rivers, 1922) and this was identified by Lwoff and Lwoff (1937) as co-enzyme I or NAD. The amounts of haemin and NAD required by the two species have been estimated in several studies under different conditions, including different basal nutrient media, either as broths or solidified with agar and from inocula that ranged from $10^{1}$ to $10^{7}$ cells.

The amount of haemin required for growth of $H$. influenzae has been stated to be $0.05-0.3 \mu \mathrm{g}$ per $\mathrm{ml}$ by Lascelles in a review (1962); chocolate agar, a traditional medium for the growth of $H$. influenzae, usually contains more than $500 \mu \mathrm{g}$ per ml. Parker and Hoeprich (1962), using a fluid medium and an inoculum of $10^{3}$ cells, found that at least $10 \mu \mathrm{g}$ per $\mathrm{ml}$ was required. Gilder and Granick (1948) determined the requirement as 0.01-0.1 $\mu \mathrm{g}$ per ml with an inoculum of $10^{7}$ cells; Biberstein and Spencer (1962) found in some instances a minimal requirement of $0.01 \mu \mathrm{g}$ per $\mathrm{ml}$ and certain strains grew even in the absence of added haemin, but they considered that amounts adequate for growth might have been present in the basal medium and the inoculum. On a solid medium with a small inoculum the haemin requirement was determined as $2 \mu \mathrm{g}$ per ml (Brumfitt, 1959). Defined media for the growth of haemophilus species contain approximately $10 \mu \mathrm{g}$ per $\mathrm{ml}$ (Wolin, 1963; Herriott et al., 1970). The results of the present study indicate that the haemin requirement of $H$. influenzae strains is between 2 and $10 \mu \mathrm{g}$ per $\mathrm{ml}$ and do not support the view, expressed by Smith, Hale and O'Callaghan (1953) and by Turk and May (1967), that strains differ widely in this respect. At concentrations of haemin of less than $2 \mu \mathrm{g}$ per $\mathrm{ml}$, colonies were small and reduced in number, and growth was not evident at concentrations of less than $0.05 \mu \mathrm{g}$ per ml. The varying amounts of haemin reported as minimal requirements may therefore be attributable to differences in the experimental conditions employed.

$H$. influenzae grew anaerobically without haemin. Four strains continued to grow anaerobically after 10 serial subcultures from small inocula without added haemin on the basal medium containing glucose. The addition of haemin to the medium was associated with an increase of growth only if nitrate was also present as a hydrogen acceptor.

None of the strains of $H$. parainfluenzae required haemin, but it was confirmed that this substance acted as a reducing agent replaceable by dithionite, and therefore appeared to be a requirement for some strains (Gilder and Granick, 1948). Under anaerobic conditions, $H$. parainfluenzae, unlike $H$. influenzae, grew poorly on the basal medium, but growth was greatly enhanced by the addition of nitrate. This accords with the findings by White and Smith (1962) that anaerobic growth of $H$. parainfluenzae was nitrate-dependent; they also showed that under these conditions the cells contained large amounts of cytochrome $a_{1}$ oxidisable by nitrate. In contrast, cytochrome was not detected in the cells of $H$. influenzae grown anaerobically without nitrate (White, 1963).

There appear to have been few determinations of the minimum requirements of NAD for growth. Most growth media for Haemophilus species include yeast extract—which contains approximately $150 \mu \mathrm{g}$ of NAD per ml—or purified 
NAD 1-3 $\mu$ g per ml (Butler, 1962; Biberstein and Spencer, 1962; Wolin, 1963). Parker and Hoeprich (1962), with a fluid medium and an inoculum of $10^{3}$ cells, obtained maximal growth of a strain of $H$. influenzae type b with an NAD concentration of $0.5 \mu \mathrm{g}$ per ml. Lwoff and Lwoff (1937), in their analysis of the physiological role of factor $\mathrm{V}$, described a strain of $H$. parainfluenzae that required as little as $0.004 \mu \mathrm{g}$ per $\mathrm{ml}$ when grown in proteose peptone broth; we have not encountered such a strain. Rather we have found that strains of $H$. influenzae grow at a lower concentration of NAD than is required for $H$. parainfluenzae. All 50 strains of $H$. influenzae grew from small inocula on the basal medium containing NAD $0.2 \mu \mathrm{g}$ per $\mathrm{ml}$, the size and numbers of colonies developing being comparable to those on control plates of chocolate agar. For $H$. parainfluenzae, a concentration of $5 \mu \mathrm{g}$ per $\mathrm{ml}$ was required to support growth of all 30 strains and only two strains showed any growth with NAD $0.2 \mu \mathrm{g}$ per ml. About half of the strains of $H$. influenzae showed growth at a concentration of NAD as low as $0.04 \mu \mathrm{g}$ per ml but no strain of $H$. parainfluenzae grew at this concentration.

In conclusion, we found no evidence that strains of the two species represent a gradient in capacity to synthesise porphyrins. The two species are distinguishable on the basis of the requirement for haemin by $H$. influenzae. $H$. parainfluenzae does not require haemin and, furthermore, probably represents a more heterogenous group and includes strains that require thiamin or oleate (Butler, 1962; Evans and Smith, 1972).

\section{SUMMARY}

Fifty strains of Haemophilus influenzae and 30 strains of $H$. parainfluenzae were clearly differentiated by the requirement of $H$. influenzae strains for haemin on a proteose-peptone basal medium and with an inoculum of 1-20 cells. No evidence was obtained for a wide range in haemin requirements; 10 strains of $H$. influenzae examined in detail required 2-10 $\mu \mathrm{g}$ haemin per $\mathrm{ml}$. The two species were dissimilar also in the amount of NAD required; the strains of $H$. influenzae grew well in the presence of NAD 0.2-1.0 $\mu \mathrm{g}$ per ml, whereas most strains of $H$. parainfluenzae required $1 \cdot 0-5 \cdot 0 \mu \mathrm{g}$ per $\mathrm{ml}$ and three strains required NAD $25 \mu \mathrm{g}$ per $\mathrm{ml}$ for optimal colony size. Nitrate was essential for the anaerobic growth of $H$. parainfluenzae but not of $H$. influenzae.

\section{REFERENCES}

Biberstein, E. L. AND Gills, M. 1961. Catalase activity of haemophilus species grown with graded amounts of hemin. J. Bact., 81, 380.

Biberstein, E. L. AND SPENCER, P. D. 1962. Oxidative metabolism of haemophilus species grown at different levels of hemin supplementation. J. Bact., 84, 916.

BRUMFIT, W. 1959. Some growth requirements of Haemophilus influenzae and Haemophilus pertussis. J. Path. Bact., 77, 95.

BUTLER, L. O. 1962. A defined medium for Haemophilus influenzae and Haemophilus parainfluenzae. J. gen. Microbiol., 27, 51.

CrawFord, J. J., Barden, L. AND KIRKMAN, J. B. 1969. Selective culture medium to survey the incidence of haemophilus species. Appl. Microbiol., 18, 646.

Cruickshank, R. 1965. Medical microbiology, 11th ed., London, p. 746. 
Evans, N. M. AND Smith, D. D. 1972. The effect of the medium and source of growth factors on the satellitism test for haemophilus species. J. med. Microbiol., 5, 509.

FILDES, P. 1921. The nature of the effect of blood-pigment upon the growth of $B$. influenzae. Br. J. exp. Path., 2, 16.

GILDER, H. AND GRANICK, S. 1948. Studies on the hemophilus group of organisms. Quantitative aspects of growth on various porphin compounds. J. gen. Physiol., 31, 103.

Herriott, R. M., Meyer, E. Y., Vogt, M. and Modan, M. 1970. Defined medium for growth of Haemophilus influenzae. J. Bact., 101, 513.

Hovig, B. AND AANDAHL, E. H. 1969. A selective method for the isolation of Haemophilus in material from the respiratory tract. Acta. path. microbiol. scand., 77, 676.

Klein, M. AND Blazevic, D. J. 1969. Differentiation of haemophilus species using satellite methods. Am. J. med. Technol., 35, 695.

Koser, S. A. 1968. Vitamin requirements of bacteria and yeasts, Springfield, Illinois, pp. 282-285.

LASCELLES, J. 1962. Tetrapyrrole synthesis in microorganisms. In The Bacteria, a treatise on structure and function, edited by I. C. Gunsalus and R. Y. Stainer, New York, vol. III, Biosynthesis, p. 335.

Lwoff, A. AND Lwoff, M. 1937. Studies on codehydrogenases. I. Nature of growth factor "V". Proc. R. Soc. B., 122, 352.

Michaels, R. H. AND Phillips, D. M. 1972. Meningitis due to Haemophilus parainfluenzae. Am. J. Dis. Child., 124, 788.

PaRker, R. H. AND HOEPRICH, P. D. 1962. Disk method for rapid identification of hemophilus species. Am. J. clin. Path., 37, 319.

Pittman, M. 1957. In Bergey's Manual of Determinative Bacteriology edited by Breed, R. J., Murray, E. D. G. and Smith, N. R., 7th ed., Baltimore, p. 406.

RIVERs, T. M. 1922. Influenza-like bacilli. Growth of influenza-like bacilli on media containing only an autoclave-labile substance as an accessory food factor. Bull. Johns Hopkins Hosp., 33, 429.

Smith, W., Hale, J. H. and O'Callaghan, C. H. 1953. Haem utilisation and nitrate reduction by Haemophilus influenzae. J. Path. Bact., 65, 229.

SteErs, E., FoltZ, E. L. AND Graves, B. S. 1959. An inocula replicating apparatus for routine testing of bacterial susceptibility to antibiotics. Antibiotics Chemother., 9, 307.

TURK, D. C. AND MAY, J. R. 1967. Haemophilus influenzae, its clinical importance, London, pp. 11 and 116.

WhITE, D. C. 1963. Respiratory systems in the hemin-requiring haemophilus species. J. Bact., 85, 84.

WhItE, D. AND SMITH, L. 1962. Haematin enzymes of Haemophilus parainfluenzae. J. biol. Chem., 237, 1332.

Willis, A. T. 1964. Anaerobic bacteriology in clinical medicine, 2nd ed., London, p. 13.

WolIN, H. L. 1963. Defined medium for Haemophilus influenzae type b. J. Bact., 85, 253.

ZINNEMANN, K. 1960. Haemophilus influenzae and its pathogenicity. Ergebn. Mikrobiol. ImmunForsch. exp. Ther., 33, 307. 